\title{
Fiscal policy and economic growth in Nigeria: a granger causality analysis
}

\author{
Ogbole F. Ogbole, S. N. Amadi and Isaac. D. Essi
}

\author{
Department of Accountancy, The Federal Polytechnic, Damaturu Yobe State, Nigeria. \\ Email: ogbolefriday@yahoo.com \\ Department of Banking \& Finance, Rivers State University of Science \& Technology \\ Port Harcourt, Nigeria. \\ Email:watiamadii@yahoo.co.uk \\ Department of Mathematics/Computer Science, Rivers State University of Science \& \\ Technology, Port Harcourt, Nigeria \\ Email: ddmetra_utibe@yahoo.com
}

\begin{abstract}
This study is on Fiscal Policy and Economic Growth in Nigeria: A Granger-Causality Analysis. We use time series data (1970-2006) in respect of the independent/explanatory variable [Fiscal Policy, measured using government expenditure (GE)] and the dependent/response variable [Economic Growth, measured using gross domestic product (GDP)], sourced from the Central Bank of Nigeria, were tested and found to be stationary (using Augmented Dickey-Fuller test) and co-integrated (using Johansen's Cointegration test). Granger causality test was further employed to test for causal relationship between these variables. The result of the analysis shows the existence of causal relationship between them with a unidirectional causality running from GE to GDP, which is in line with a priori expectation. We conclude that in the period under study, fiscal operations in Nigeria, to some extent, caused some economic growth in the country, though the precise extent is a subject of further study. We recommend refocusing Fiscal Policy to ensure: appropriate policy mix, refocusing GE to increase output, increasing government capital/investment expenditure to exceed consumption expenditure, increasing punitive measures against fraud and mismanagement of public funds and raising Nigeria to the status of a producer and exporting nation.
\end{abstract}

Keywords: Fiscal Policy; Economic Growth; Granger Causality Analysis

\section{INTRODUCTION}

Several empirical studies have supported the assertion of the existence of a relationship between fiscal policy (FP) and economic growth (EG) in several economies of the world following the Keynesian philosophy that pulled depressed economies out of depression during the great depression era. Empirical studies in some developing economies tell the same story. Ekpo (1994), in Adeoye (2006), in Nigeria, found a positive correlation between public investment and $E G$ as the former crowded in private investment. Adeoye's (2006) study covered a different time frame of the Nigerian economy and established a negative relationship between public investment and EG (this time, public investment crowded-out private investment). From the study of a panel of 40 African countries, Aregbeyen (2007) established a positive and significant correlation between government capital and public investment and EG, while he found that current and consumption expenditures were negatively associated with it. Other studies also confirm either a negative or a positive correlation/relationship between FP (with government expenditure, public investment or related variables used as proxies) and EG.

In this study we have used government expenditure (GE) and gross domestic product (GDP) as indices for FP and EG respectively. It is important to note that correlation does not necessarily imply a causal relationship. There is however dearth of causal studies of the Nigerian economy in recent years, especially in the $21^{\text {st }}$ century, in which a causal relationship was established between FP and EG. This therefore forms the inspiration behind this study. Thus, the main objective of this study is to 
investigate the existence of causal relationship between FP and EG in the period 1970-2006 and to determine the direction of causality. This constitutes our point of departure. The hypotheses to be tested are thus:

$$
\begin{aligned}
& H_{1} \text { : GDP does not granger-cause GE } \\
& H_{2} \text { : GE does not granger-cause GDP }
\end{aligned}
$$

\section{Conceptual framework/review of related} literature: Government's deliberate actions towards spending money and for levying taxes aimed at influencing macro-economic variables so as to achieve desired macroeconomic objectives is referred to as fiscal policy. The objectives include sustainable economic growth, high employment, low inflation (Microsoft Corporation, 2004) and balance of payment equilibrium. Thus, the combined effects of increased government spending and a reduction in taxes usually pull an economy out of a recession, while reduced spending and/or increased taxes tend to slow down an economic boom (Dornbusch and Fischer, 1990).Economic Growth is the process whereby there is a steady long-term increase in real GDP and improvement in living standards; and "movements in real GDP are the best widely available measure of the level and growth of output" (Samuelson and Nordhaus, 1998).

Theoretically, GE is positively correlated with GDP (Anyanwu (1997), McConnell and Brue (2005) and Onoh (2007)). The underlying assumptions however are that: (1) the economy is operating below the fullequilibrium level and (2) the expenditure is channeled to productive investments to increase output of goods and services, and to increase national income. As a result, increase (decrease) in GE may lead to increase (decrease) in GDP. However, GE should not be increased indefinitely to avoid inflationary pressures from setting in. The increase should continue only to the point of achieving full-employment level.

Ekpo (1994)in Adeoye (2006) observed that in Nigeria (1960-1990) public spending on infrastructure crowded in private investment and thus spurs economic growth (though private investment was reported to be more efficient than public investment).According to Aregbeyen (2007), the studies of Devarajan et al (1996), Fuente's (1997), Amin (1998), Kneller et al (1999)and Bose et al (2003) indicate correlation between FP and EG. Devarajan et al (1996) found that productive government expenditure enhanced economic growth. Fuente's (1997) investigation of 21 OECD countries (1965-1995) showed that public expenditures sometimes tend to crowd-out private investment through reduction of disposable income and savings and may exert some negative "externality" effect on the level of productivity. In Cameroon, Amin (1998) also observed that public expenditure on infrastructure had enormous returns and thus enhanced growth.

Furthermore, the study conducted by Kneller et al (1999) confirmed the studies of Devarajan et al (1996) and Fuente (1997). Bose et al (2003) found that government capital expenditures in GDP is positively and significantly correlated with economic growth but that the growth effect of current expenditure is insignificant. Aregbeyen's (2007) study of a panel of 40 African countries (including Nigeria) revealed that Government Capital and public investment expenditures were significantly positively associated with economic growth while current and consumption expenditures were negatively associated. The former category of expenditure was in less proportion of government total expenditure than the latter category. Aregbeyen (2007) believed that though government expenditures were necessary for economic growth, the quality of such expenditure is of more important consideration. According to him the quality of government expenditures is the distribution of government expenditures between capital and consumption purposes on one hand and current and consumption purposes on the other hand.

Despite several studies on fiscal policies, Adeoye (2006) still observed that "the debate on the usefulness of fiscal policy as a tool for promoting growth and development remains inconclusive, given the conflicting results of current research". He opined that while the studies of Thornton (1990), Lin and Liu (2000) indicated a net positive effect, those of Baily (1980) and Feldstein (1980) indicated a negative net effect. In addition, he also cited the studies of Aghevli and Sassan pour (1982), Ram (1986), Grossman (1988), Ariyo (1993), Easterly and Rebolo (1993), Kouassy and Bohoum (1993, 1994), Ekpo (1994), Japelli and Meana (1994), Lin and Liu (2000) as being instructive . Ram (1986), using cross country regressions found that while growth in general is positively correlated with rate of change in total public expenditure, it is negatively correlated with the level of such expenditure. Again, Ram (1986) and Grossman (1988) reported positive 
relationships between government fiscal deficit and economic growth.

Also, Kouassy and Bohoum (1994) found, in Cote d'Ivoire, that public investment had a net crowding-in affect on the private sector and a positive impact on economic growth. Ekpo's (1994) study in Nigeria (1960-1992) revealed that public sector investment in infrastructure complements the private sector and implicitly spurs growth. Furthermore, a cross country study conducted by Jeppelli and Meana (1994) revealed that public expenditures on investment and consumption impacted differently on economic activity. Public investment was found to stimulate output thereby increasing government revenues (which, in turn, enhance government spending).

Also, the study of Lin and Liu (2000) on China's economy showed that fiscal decentralization significantly contributed to economic growth rate mainly through efficient resources allocation rather than by inducing additional investment. (This agrees with the hypothesis that fiscal decentralization can increase economic efficiency). Adeoye (2006) examined the effects of fiscal policy on growth of the Nigerian economy (1970-2002). The result showed that capital expenditure as a ratio of GDP (used as proxy for public investment) exerted a negative impact on output growth by having a crowding-out effect on private investment. Thus from the foregoing empirical studies it may be inferred that the relationship between FP and EG may be either negative or positive depending on varying prevailing economic factors in the economies in question. However, our point of departure in this study is to investigate specifically the existence of causal relationship between FP and EG and the direction of causality, not merely establishing a correlation between them.

Methodology and model specification: This study adopts a causal study design using Granger causality test as the main statistical tool. The time series data (1970-2006) used (obtained from the 2006 Statistical Bulletin of the Central Bank of Nigeria) were tested for stationarity [using Augmented Dickey-Fuller (ADF) test] and for cointegration (using Johansen's cointegration test). FP, the independent variable, is measured by GE as was also used by Egwaikhide (2005). EG, the dependent variable is measured by gross domestic product (GDP). Our analysis is to see whether movements in GDP in the period of study were caused by government's fiscal spending.
For the stationarity test, as a decision rule, if t-ADF (absolute value) $>\mathrm{t}-\mathrm{ADF}$ (critical value), reject $\mathrm{H}_{0}$ of non stationarity (otherwise accept $\mathrm{H}_{1}$ ). The level of significance $\alpha$ is 0.05 . The Johansen's co-integration test seeks to show the number of cointegrating equations (CEs), if the variables have long-run relationship, that is, are cointegrated. For the test for causality, the Granger Causality equation is:

$$
\begin{aligned}
& \mathrm{Y}_{\mathrm{t}}=\alpha+\sum_{i=1}^{n} \alpha_{i} X_{t-i}+\sum_{j=1}^{n} \beta_{i} \mathrm{Y}_{t-j}+\mu_{1 t} \\
& \mathrm{X}_{\mathrm{t}}=\mathrm{b}+\sum_{i=1}^{n} \lambda_{i} X_{t-i}+\sum_{i=1}^{n} \delta_{i} \mathrm{Y}_{t-i}+\mu_{2 t}
\end{aligned}
$$

Where:

$Y$ and $X$ represent dependent and independent variables respectively. It is assumed that the disturbances $\mu_{1 \mathrm{t}}$ and $\mu_{2 t}$ are uncorrelated. The $\mathrm{F}$ statistic is used for the joint test of the hypotheses that in Equation (1) $\alpha_{1}=\alpha_{2}=\ldots=\alpha_{n}=0$; and in Equation (2) $\delta_{1}=\delta_{2}=\ldots \delta_{\mathrm{n}}=0$. The null hypothesis in equation (e) is that " $X$ does not Granger - cause $Y$ " and in (f) that "Y does not Granger - cause X" (Kareem, 2007).

Data analyses and discussion of findings: The stationarity tests show that both GDP and GE are stationary

[-8.795(absolute value)]> -3.595(critical value), $p$ value, $0.00<\alpha, 0.05$; and -5.62 (absolute value) $>$ 3.58 (critical value), $p$-value, $0.0005<\alpha, 0.05$ respectively).Johansen's cointegration test shows that the GDP and GE series are cointegrated, with Trace test indicating at least one(1) CE. From the Granger Causality test results we fail to reject $\mathrm{H}_{1}$, implying that GDP does not Granger-cause GE(p-values 0.078 and 0.45 are both greater than $\alpha, 0.05$ using lags of 1 and 4 respectively). On the other hand, we reject $\mathrm{H}_{2}$, which implies that GE Granger-causes GDP and hence there is a unidirectional causality with the direction of causality running from $\mathrm{GE}$ to $\mathrm{GDP}$ (p-values approximately 0.015 and 0.043 are both less than a, 0.05 using lags of 1 and 4 respectively). The finding that GE Granger-causes GDP somewhat agrees with the a priori expectation that when GE is directed to productive channels in an economy output(GDP) tends to increase(Anyanwu (1997), McConnell and Brue (2005) and Onoh (2007)),though such relationships may not directly imply causality as we have earlier observed from the many empirical studies cited above. 
A strong correlation is however a necessary condition for causality. Furthermore, it is important to note that it is the causal relationship that actually strongly shows the general level of effectiveness of FP for the entire period 1970-2006.

This finding may imply that fiscal policy in Nigeria, in the period of study, influences economic growth to some extent since a causal relationship has been established between FP and EG in the period. It is possible that fiscal operations of the government in the period have a measure of effectiveness in causing some form of economic growth in Nigeria. Practically speaking this finding is partly supported by the periodic increase in employment and in the provision of some basic infrastructure in some sectors of the economy during the period. However, from experience we know that generally some factors limit the effectiveness of fiscal policy: poor quality of $\mathrm{GE}$; inappropriate macroeconomic policy mix; persistent budget deficits; corruption and misappropriation of public funds; improper timing of fiscal policies; time lags between preparation, approval and execution of budgets and fiscal policies, etc. These factors are likely to have limited the effectiveness of fiscal policy operations in the period since they were prevalent.

Conclusion and recommendations: From the findings of this study we may conclude that there exists causal relationship between FP and GDP in Nigeria in the period 1970-2006 as GE Grangercauses GDP with a unidirectional causality running from GE to GDP. Thus, fiscal operations of the government in the period have a measure of effectiveness in causing some form of economic growth in the period. However, the precise degree or extent of effectiveness of $F P$ in causing $E G$ is a subject of further studies. Based on the finding we recommend as follows:

i There should be appropriate policy-mix to ensure that FP measures are not mitigated by conflicting macroeconomic policies.

ii. Fiscal policies should emphasize redirection of GE to productive channels in the economy so as to increase output (GDP).

iii. Government capital and investment expenditures should constitute a greater proportion of total government expenditures than recurrent and consumption expenditures so as to provide the needed infrastructure as a pivot for sustained economic development. iv. Since fraud and public funds embezzlement (among other factors) have become the bane of Nigeria's economic growth and development over the years, public funds embezzlement should attract a more severe penalty as a disincentive to those who see public office as a springboard to leap fast to a height of wealth and self actualization at the expense of the impoverished majority.

$\mathrm{V}$.The consumption-based economy of the country has made it to be largely importdependent resulting in prolonged periods of balance of payment deficits. Thus, fiscal policy should refocus making Nigeria a producer, oil and non-oil exporting nation that de-emphasizes importation.

\section{REFERENCES}

Adeoye, T. (2006). Fiscal Policy and Growth of the Nigerian Economy: An Empirical Perspective. Ibadan: NISER monograph series No. 3.

Anyanwu, J. C. (1997): Nigerian Public Finance. Onisha: Joanee Educational Publishers Ltd.

Aregbeyen,O.(2007): Public Expenditure and Economic Growth. African Journal of Economic Policy. Ibadan (Nigeria): University of Ibadan Press.1 (1)

Dornbusch, R. and Fischer, S. (1990): Macroeconomics (5 $5^{\text {th }}$ ed)

w York: McGraw-Hill Publishing Company.

$\mathrm{Ne}$

Egwaikhide, F.O. (2005): Fiscal policy posture in Nigeria in: Owosekum, A. A; Ojowu, O.; and Egwaikhide (Editors): Contemporary Issues in Management of the Nigerian Economy Ibadan: Nigerian Institute of Social and Economic Research P.1-21

Gujarati, D.N.(2003): Basic Econometrics $4^{\text {th }}$. Ed. New Delhi: Tata Mc Graw- Hill Publishing Company Ltd.

Kareem, O. I.(2007): Globalization and Employment in developing economies: The Nigerian Experience in Employment Generation in Nigeria .Ibadan: The Nigerian Economic Society.

McConnell and Brue (2005): Economics New York: McGrawHill and Irwin.

Microsoft Corporation (2004): Microsoft Encarta Encyclopedia

Onoh (2007): Dimensions of Nigeria's Monetary and Fiscal Policies-Domestic and External. Aba: Astra Meridian Publishers.

Samuelson, P. A. and Nordhaus, W. D. (1998): Economics $\left(16^{\text {th }}\right.$ ed). New Delhi: Tata McGraw-Hill Publishing Company Ltd. 